\title{
RISK ASSESSMENT AND MITIGATION FOR BETTER SAFETY: CASE STUDY OF KEMAMAN PORT
}

\author{
MOHAMAD IKHRAM BIN MOHAMAD RAUZILAN AND MOHAMMED ISMAIL RUSSTAM \\ SUHRAB $^{*}$
}

Faculty of Maritime Studies, University Malaysia Terengganu, 21030 Kuala Nerus, Terengganu, Malaysia

*Corresponding author: m.ismail@umt.edu.my

http://doi.org/10.46754/umtjur.2021.04.007

\begin{abstract}
The increase in awareness and responsibilities among stakeholders in a port environment has made safety evaluation an operational priority. Operating a port is a high-risk activity with underlying potential for accidents and loss of lives, besides causing massive property and environmental damage. Kemaman Port has multiple operations and handles volatile chemicals that may lead to disaster if an accident were to occur due to negligence. Therefore, the safety tools at the port have to suit a terminal specialized in handling liquid chemicals. To determine risk level at the port, assessment may be conducted using the hazard identification method (HAZID) to determine the hazards and risk matrix. The "As low as reasonably practicable" (ALARP) principle should be adhered to in determining which risk is tolerable or intolerable. In this study, the hazard and risk data at Kemaman Port were obtained through literature review and engagements with experts. As a result, eight main hazards were identified and the risk matrix was used to find the highest frequency and consequences of the hazards, besides the risk probability during operations. The overall results may demonstrate a significant improvement to the safety of port operations.
\end{abstract}

Keywords: Port safety, safety, risk assessment, risk matrix

\section{Introduction}

Kemaman Port is a deep seawater port in the east coast state of Terengganu in Peninsular Malaysia. Figure 1 shows the layout of Kemaman Port that is capable of handling ships with more than 150,000 DWT, besides general, dry bulk and liquid bulk cargoes. The port operator Konsortium Pelabuhan Kemaman Sdn Bhd $(\mathrm{KPK})$ - is capable of running a specialized terminal for chemical cargoes known as the liquid chemical berth (LCB) in the port's East Wharf. As Kemaman Port executes multiple operations simultaneously, there is a high risk of a massive accident if safety precautions are neglected. There are a lot of possible hazards within the operations and conditions of the port itself. Naturally, most of the hazards will be concentrated on the LCB. 


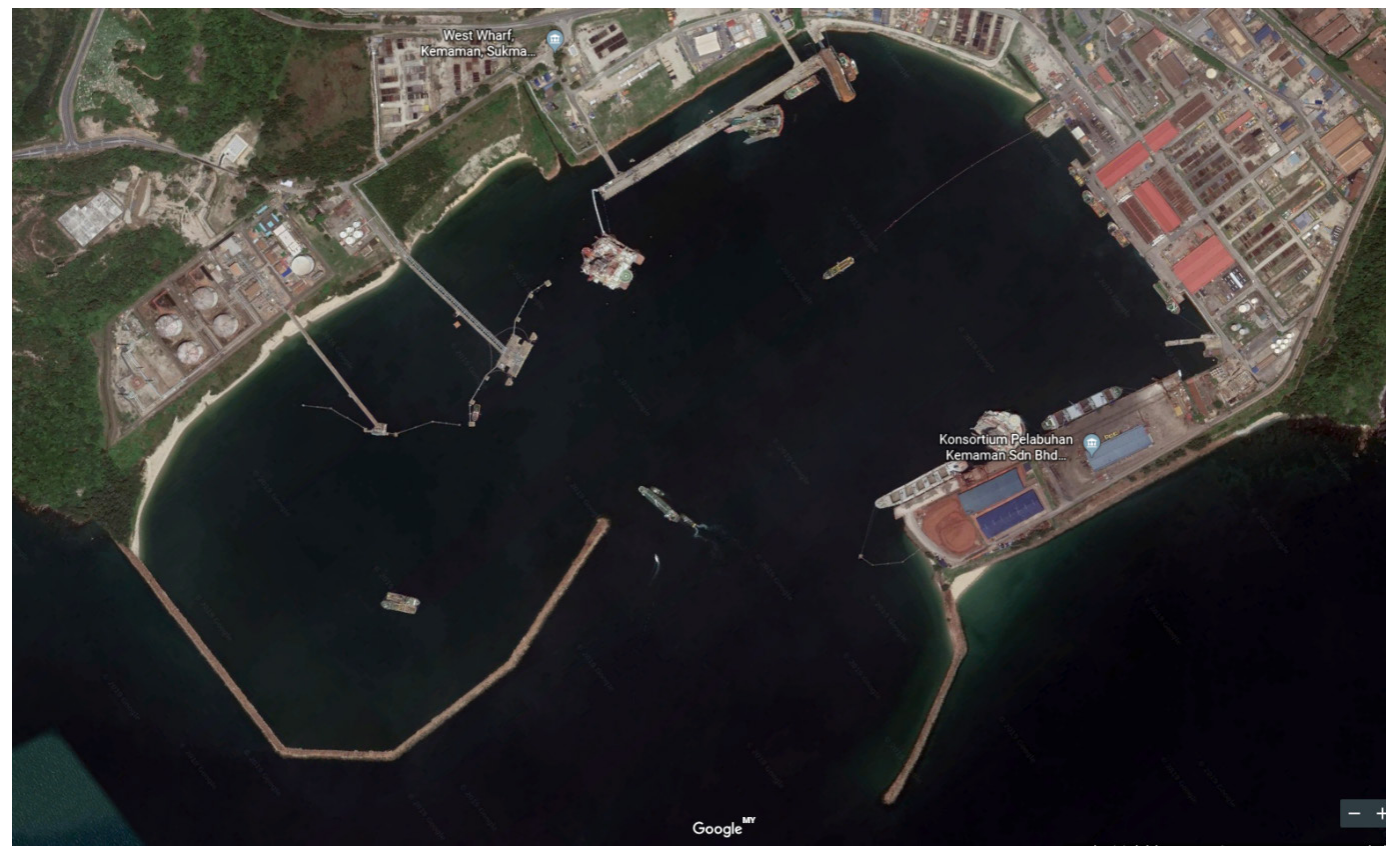

Figure 1: Location of Kemaman Port ( Source: Google Earth, 2019)

In modern transport networks and systems, seaports play an important role and are responsible for processing more than $80 \%$ of international trade flow. Their operations and activities are fraught with hazards that may lead to the loss of human lives, besides causing damage to properties and the environment, along with a huge economic loss among the stakeholders. According to the International Maritime Organization (IMO), the combination of frequency and severity of consequences may be defined as a risk. Frequency means the likelihood of accidents to occur, while consequences refer to severity in terms of the number of people affected, property damage, amount of chemical spill, environmental destruction, outage time, mission delay and money lost.

Risks may be defined as the potential for uncontrolled loss of something of value, or rewards gained from exposure to a hazard or a result of an event (Clack, 1997). On the other hand, Kuo (1997) stated that risks are things that lead to an undesired result in the process of meeting an objective. This may include casualties or death, harm to property, mischief to nature and many others. Risk analysis involves hazard identification (Hazid), event probability calculations and analysis of consequences using the risk matrix. Moreover, risk management refers to the practice of identifying potential risks in advance, analysing them, and proposing mitigatory steps to minimize the adverse effects.

Seaport safety is an important perspective in ensuring the efficiency of port operations, thus attracting much research related to its risks, such as the organizational, operational and economic perspectives (Legato \& Monaco, 2004). Risk analysis persistently involves many aspects, such as port competition, efficiency analysis, geographical analysis, spatial evolution, port policy and others (Yang et al., 2014).

Port traffic risks follow a particular pattern, and ship collision is the most common accident (Yip, 2008). Accidents have been increasing among chemical and petrochemical tankers, and cargo ships over the past decade. This has pressured policymakers to improve safety and protect people and the environment. The risks have been analyzed in terms of vessel traffic at 
sea to establish safe ship operation and develop new strategies. In the approach to safety and loss prevention, it is clear that many ports and policies are evolving towards better risk management as opposed to technical solutions. The reason for this evolution is because the safety management system is prone to failure even after the design standards and technical solutions have been improved. Failure analysis has identified main causes in safety management system, even when the accidents are caused by frontline technical and human control systems.

The international shipping industry has now moved to a proactive approach to safety methods through what is known as the Formal Safety Assessment (FSA). FSA is introduced by the IMO as a rational and systematic method to process risk related to maritime safety. FSA is a structured and systematic methodology, aimed at enhancing maritime safety, including protection of life, health, property and maritime environment by using risk analysis and costbenefit analysis (IMO, 2002). The basic philosophy of the FSA is that it can be used as a tool to facilitate a transparent decision-making process, and also provides a means of being proactive and enabling potential hazards to be considered before a serious accident occurs (Montewka, 2014).

\section{Materials and Methods}

\section{Data Collection}

First objective

The first objective was to identify the hazards in Kemaman Port operation. To achieve this, port experts were interviewed for their opinion. According to Adam (2007), talking to people might be an important element to obtain research data. The experts were from three departments of KPK, namely the Marine Service Department, Operation Department and Safety Department. The expert representatives were:

i. Captain Mohd Kamarul Mamat, marine manager;

ii. Syed Ahmad Hasbullah, health safety officer; iii. Nurul Syuhada Rani, executive planner;

iv. Saufi - firefighter and mooring handler;

v. Asyraf - marine service staff; and

vi. Ammar - marine service staff

Furthermore, a survey via questionaire was conducted to observe the risk of hazards that existed in Kemaman Port operation. The questionnaire was distributed to selected respondents, who were experts on hazards in the port. The questionnaire was constructed to collect the respondents' demographic information and risk matrix data after the hazards had been verified. Additionally, journals, books and reports were also used as references to produce relevant questions for the interview and to obtain details on the hazards that existed in Kemaman Port. For this part, it was mostly secondary data that was used to gather the information.

\section{Second Objective}

The second objective was to evaluate the risk of hazards in Kemaman Port operations. Based on the hazards obtained in the first objective, a questionnaire on risk matrix that consisted of frequency and severity of hazards was distributed among among experts and staff in the Marine Service Department, Operation Department and Safety Department of KPK.

\section{Third Objective}

The third objective was to propose risk mitigation in Kemaman Port operations. Risk mitigation and control options would be derived based on the results of the second objective, Interviews with Kemaman Port experts were conducted to obtain possible risk mitigation or risk control options.

\section{Data Analysis}

\section{First Objective Analysis}

The first objective intended to identify the hazards that existed in Kemaman Port operations. From the interviews conducted, the hazards 
in Kemaman port were determined through quantitative analysis. Together with secondary data from journals and books, the most suitable port hazards were identified. According to the HAZID method, frequent and high severity were factors that were given priority in determining the port hazards.

\section{Second Objective Analysis}

The second objective was a risk assessment on the hazards in Kemaman Port operations. Based on the questionnaire answers, the risk for every hazard would be calculated using the risk matrix formula. The calculated risks were analyzed based on the ALARP principle to finalize the risk level. The formula for the risk matrix is stated in Equation 1 (Eq. 1).

$$
\mathrm{R}=\mathrm{P} \times \mathrm{C}
$$

where $\mathrm{R}$ is the risk, $\mathrm{P}$ is probability and $\mathrm{C}$ represents the consequence.

\section{Third Objective Analysis}

The third objective was to propose mitigation steps to overcome the risks in Kemaman Port operations. The qualitative problem-solving approach was used to analyze the data from port staff interviews. Data from the interviews were analyzed based on risk level, needs and cost to evaluate risk mitigation.

\section{Results and Discussion}

\section{First Objective}

From literature review and interviews, eight main hazards were identified in Kemaman Port. Table 1 shows the existing hazards and risks that had been verified.

Table 1: Hazards and Risks identified in Kemaman Port

\begin{tabular}{|c|c|c|}
\hline & Hazards & Risks \\
\hline 1 & $\begin{array}{l}\text { Inner Harbor } \\
\text { (Ship contact with jetty or quay during berthing } \\
\text { operations) }\end{array}$ & Ships may collide with the berth, damaging the hull. \\
\hline 2 & $\begin{array}{l}\text { Cargo transfer between ship and wharf } \\
\text { (Equipment failure, human error) }\end{array}$ & $\begin{array}{l}\text { Ropes may break and cargoes may drop while being } \\
\text { loaded, causing damage to goods and ships, besides } \\
\text { endangering workers. }\end{array}$ \\
\hline 3 & $\begin{array}{l}\text { Mooring hazard } \\
\text { (Failure of ship mooring, lead-based mooring } \\
\text { equipment, shattered ropes) }\end{array}$ & $\begin{array}{l}\text { Backlash if the mooring rope snaps on the dock or jetty. } \\
\text { This may cause damage to machines and equipment } \\
\text { around the docking area, besides endangering workers. }\end{array}$ \\
\hline 4 & $\begin{array}{l}\text { Falling objects } \\
\text { (Occurs during stacking and stowing) }\end{array}$ & Damage to goods and ship structure. \\
\hline 5 & $\begin{array}{l}\text { Exposure to hazardous agents } \\
\text { (Dust and respiratory irritants, flammable } \\
\text { cargo) }\end{array}$ & $\begin{array}{l}\text { Causing adverse effects on health like breathing } \\
\text { difficulties and possibility of fires. }\end{array}$ \\
\hline 6 & $\begin{array}{l}\text { Slipping, tripping or falling down at port areas. } \\
\text { (Uncovered drains, slippery floors, during } \\
\text { mooring of ships) }\end{array}$ & $\begin{array}{l}\text { May cause injury or death to port workers, especially } \\
\text { if they fall overboard. }\end{array}$ \\
\hline 7 & $\begin{array}{l}\text { Working at heights } \\
\text { (Carrying out trimming, sheeting, container } \\
\text { lashing, securing loads, accessing the hold and } \\
\text { working onboard) }\end{array}$ & $\begin{array}{l}\text { Falls may end up fatal, while those injured in the neck } \\
\text { and spinal cord may become disabled. }\end{array}$ \\
\hline
\end{tabular}


Fatigue

8

(Lack of job rotation, unpredictable ship arrivals, high temperatures, high noise levels,

long, repetitive and difficult working hours)

\section{Second Objective}

Table 2 shows the ranking of hazards in Kemaman Port based on the questionnaires answered by port representatives. The risks matrix formula in Equation 1 was used to
Affects the workers' ability to concentrate and make decisions, thereby increasing errors in judgment and affecting productivity and performance.

Table 2: Risk Matrix Results

\begin{tabular}{|c|c|c|c|c|c|}
\hline Hazards & 1 & 2 & 3 & 4 & 5 \\
\hline Inner harbour quays & $(1-5)$ & $(6-10)$ & $(11-15)$ & $(16-20)$ & $(21-25)$ \\
\hline Cargo transfer between ship and wharf & $(1-5)$ & $(6-10)$ & $(11-15)$ & $(16-20)$ & $(21-25)$ \\
\hline Mooring hazard & $(1-5)$ & $(6-10)$ & $(11-15)$ & $(16-20)$ & $(21-25)$ \\
\hline Falling object & $(1-5)$ & $(6-10)$ & $(11-15)$ & $(16-20)$ & $(21-25)$ \\
\hline Chemical agents & $(1-5)$ & $(6-10)$ & $(11-15)$ & $(16-20)$ & $(21-25)$ \\
\hline Slips, trips, falls at port & $(1-5)$ & $(6-10)$ & $(11-15)$ & $(16-20)$ & $(21-25)$ \\
\hline Work at height & $(1-5)$ & $(6-10)$ & $(11-15)$ & $(16-20)$ & $(21-25)$ \\
\hline Fatigue & $(1-5)$ & $(6-10)$ & $(11-15)$ & $(16-20)$ & $(21-25)$ \\
\hline
\end{tabular}

\section{Third Objective}

Risk mitigation or risk control options were proposed for Kemaman Port to avoid untoward calculate the risk of every hazard. The risks were ranked based on the ALARP principle as shown in Table 1 . The probability and severity data containing safety assessments as per the questionnaire were calculated and the results are also shown in Table 2.

Table 3: Risk mitigation recommendation by Kemaman Port Experts

\begin{tabular}{ll}
\hline Hazards & Risk Mitigation \\
\hline Inner harbour quays & $\begin{array}{l}\text { Proper and clear instructions from pilot to mooring gang, two-way communication } \\
\text { between pilot and mooring gang. Tug master needs to be familiar with local callsigns } \\
\text { in berthing operations, besides having good competency. }\end{array}$ \\
\hline Cargo transfer & $\begin{array}{l}\text { Loading and unloading management plan needs to be implemented together with } \\
\text { emergency response plans. }\end{array}$ \\
\hline Mooring hazards & $\begin{array}{l}\text { Regular check on mooring line before berthing, maintenance plan schedule for } \\
\text { mooring line, proper and clear instruction from the pilot, wearing personal protective } \\
\text { equipment (PPE), standing clear of lines being thrown and ready to pick up, staying } \\
\text { out of snapback zone, working in a group (mooring gang), and staying out of bights } \\
\text { or eyes of the mooring line. }\end{array}$ \\
\hline Falling objects & $\begin{array}{l}\text { Loads must be secured, especially during movement around the dock. Working in a } \\
\text { safe system to ensure that pre-slung and lose loads may be lifted safely. All securing } \\
\text { equipment must be adequately inspected and maintained, such as twist locks and } \\
\text { lashing bars. }\end{array}$ \\
\hline
\end{tabular}




\begin{tabular}{ll}
\hline Hazardous agents & $\begin{array}{l}\text { A safe system of work must be adhered to before entering the cargo hold; grabs must } \\
\text { be properly maintained and used in accordance with safety regulations to reduce dust } \\
\text { generation; and vehicle exhaust inside a ship's hold should be monitored. }\end{array}$ \\
\hline $\begin{array}{l}\text { Slipping, tripping } \\
\text { and falling at port }\end{array}$ & $\begin{array}{l}\text { All port areas need to be clean and in good condition at all times, all operational areas, } \\
\text { emergency routes and port access should be free of clutter that may result in accidents. } \\
\text { The port supervisor or person in charge must ensure safe access and egress. }\end{array}$ \\
\hline Working at heights & $\begin{array}{l}\text { Working at heights should be avoided whenever possible. If workers need to work } \\
\text { at high places, they should use proper equipment to avoid falls. The working height } \\
\text { should be mitigated to reduce the impact of a fall (Need to be instructed or supervise } \\
\text { by others, and proper training or other means). }\end{array}$ \\
\hline Fatigue & $\begin{array}{l}\text { Management is responsible for preventing excessive wake periods at work and } \\
\text { formulating well-planned schedules. Work should be avoided at places with extreme } \\
\text { temperatures, or the exposure being minimized with job rotations. }\end{array}$ \\
\hline
\end{tabular}

To summarize, most of the hazards in Kemaman Port were controllable and could be mitigated

\section{Conclusion}

Safety is a very important factor in the port environment. To ensure operations could run without untoward incidents, risk assessment needs to be constantly carried out. The top management and stakeholders of the port need to be aware of risks which could potentially harm workers and affect operations. Objective of this study was to identify the hazards in Kemaman Port, evaluating the risks and proposing risk mitigation or control options to improve safety of port operations. Most of the hazards in Kemaman port were controllable and could be reduced. As a whole, the results of this research may be utilised to improve safety in Kemaman Port.

\section{Acknowledgements}

The authors like to thank the thesis committee of Universiti Malaysia Terengganu for their feedback in this study. Special gratitude also goes to the experts and staff members of Konsortium Pelabuhan Kemaman for sharing their knowledge in the interviews and questionaire survey.

\section{References}

Chlomoudis, C. I., Kostagiolas, P. A., \& Pallis, P. L. (2012). An analysis of formal risk assessments for safety and security in ports: Empirical evidence from container terminals in Greece. Journal of Shipping and Ocean Engineering, 2(April 2017), 45-54. Retrieved from http://www. davidpublishing.com/davidpublishing/ Upfile/3/20/2012/2012032080998401.pdf.

Cho, H. S., Lee, J. S., \& Moon, H. C. (2018). Maritime risk in seaport operation: A crosscountry empirical analysis with theoretical foundations. Asian Journal of Shipping and Logistics, 34(3), 240-248. https://doi. org/10.1016/j.ajsl.2018.09.010.

Cirjaliu, B., Weinschrott, H., Gaureanu, A., \& Boatca, E.-M. (2016). A proposal for risk assessment management in a transport company. Procedia Economics and Finance, 39(November 2015), 229-234. https://doi. org/10.1016/s2212-5671(16)30317-3

Gratt, L. B. (2012). Risk analysis or risk assessment; a proposal for consistent definitions. Uncertainty in Risk Assessment, Risk Management, and Decision Making, 241-249. https://doi.org/10.1007/978-14684-5317-1_20.

Grote, M., Mazurek, N., Gräbsch, C., Zeilinger, J., Le Floch, S., Wahrendorf, D. S., \& Höfer, T. (2016). Dry bulk cargo shipping - An overlooked threat to the marine environment? Marine Pollution Bulletin, 110(1), 511-519. https://doi.org/10. 
Haapasaari, P., Helle, I., Lehikoinen, A., Lappalainen, J., \& Kuikka, S. (2015). A proactive approach for maritime safety policymaking for the Gulf of Finland: Seeking best practices. Marine Policy, 60, 107-118. https://doi.org/10.1016/j. marpol.2015.06.003.

Maanu, K., \& Ora, K. (2004). Final guidelines for port \& harbour risk assessment and safety management systems in New Zealand maritime safety authority of New Zealand maritime safety keeping your sea safe for life.

Office, B. R. D. (n.d.). Proposals for developing a common approach to risk assessment. Common Approach to RA - Overview PP v0.3.

Parra, N. M., Nagi, A., \& Kersten, W. (2018). Risk assessment methods in seaports: A literature review.

Perkovic, M., Gucma, L., Przywarty, M., Gucma, M., Petelin, S., \& Vidmar, P. (2012). Nautical risk assessment for LNG operations at the port of Koper. Strojniski Vestnik/Journal of Mechanical Engineering,
58(10), 607-613. https://doi.org/10.5545/ sv-jme.2010.265.

Trbojevic, V. M., \& Trbojevic, V. M. (2001). Linking risk assessment of marine operations to safety management in ports. MTS Conference.

Trbojevic, Vladimir M., \& Carr, B. J. (2000). Risk-based methodology for safety improvements in ports. Journal of Hazardous Materials, 71(1-3), 467$480 . \quad$ https://doi.org/10.1016/S03043894(99)00094-1.

Zhang, J., Teixeira, Â. P., Guedes Soares, C., \& Yan, X. (2018). Quantitative assessment of collision risk influence factors in the Tianjin port. Safety Science, 110, 363-371. https:// doi.org/10.1016/J.SSCI.2018.05.002

Zuritah, A. K., Roslina, M., Norazli, O., Astuty A., Mohd N. M., Siti H. A-B., \& Firdaus M-S. (2020). Risk management framework for handling and storage of cargo at major ports in malaysia towards port sustainability. Sustainability, 12(2), 516. https://doi. org/10.3390/su12020516. 
